\title{
Modulated Fragmentation of Proapoptotic Peptide Nanoparticles Regulates Cytotoxicity
}

\author{
Tomoya Suma, ${ }^{\dagger}$ Jiwei Cui, ${ }^{\dagger}$ Markus Müllner, ${ }^{\S}$ Shiwei Fu, ${ }^{\dagger}$ Jenny Tran, ${ }^{\dagger}$ Ka Fung Noi, ${ }^{\dagger}$ Yi Ju, ${ }^{\dagger}$ and \\ Frank Caruso ${ }^{* \dagger}$
}

${ }^{\dagger}$ ARC Centre of Excellence in Convergent Bio-Nano Science and Technology, and the Department of Chemical and Biomolecular Engineering, The University of Melbourne, Parkville, Victoria 3010, Australia

${ }^{\S}$ Key Centre for Polymers and Colloids, School of Chemistry, The University of Sydney, Sydney, NSW 2006, Australia

\begin{abstract}
Peptides perform a diverse range of physiologically important functions. The formulation of nanoparticles directly from functional peptides would therefore offer a versatile and robust platform to produce highly functional therapeutics. Herein, we engineered proapoptotic peptide nanoparticles from mitochondria-disrupting KLAK peptides using a template-assisted approach. The nanoparticles were designed to disassemble into free native peptides via the traceless cleavage of disulfide-based cross-linkers. Furthermore, the cytotoxicity of the nanoparticles was tuned by controlling the kinetics of disulfide bond cleavage, and the rate of regeneration of the native peptide from the precursor species. In addition, a small molecule drug (i.e., doxorubicin hydrochloride) was loaded into the nanoparticles to confer synergistic cytotoxic activity, further highlighting the potential application of KLAK particles in therapeutic delivery.
\end{abstract}

\section{INTRODUCTION}

Peptides have highly sophisticated and diverse physiological functions that remain challenging to mimic using synthetic molecules. The roles of peptides range from signaling for regulation of immunity, reproduction, and homeostasis $^{1,2}$ to self-defense against pathogens or predators. $^{3}$ Advancements in genetic engineering, computational design, and chemical synthesis have allowed the creation of diverse artificial peptide variants that have superior functionality and stability when compared with naturally derived peptides. ${ }^{4-6}$ The number of approved peptide-based drugs is increasing, with applications in areas including gastrointestinal disorders, anemia, and cancer. ${ }^{1,5}$ Nevertheless, the biomedical application of peptides is still limited because they generally exhibit poor membrane permeability, are prone to enzymatic degradation and renal clearance, and have limited accumulation at target sites. Nanoparticles have shown promise as delivery carriers of various therapeutics such as small molecule drugs, proteins, nucleic acids, and peptides. ${ }^{7,8}$ Various peptide delivery formulations have been developed, including liposomes, nanogels, polyplex particles, and inorganic nanoparticles..$^{9-11}$ However, challenges still remain regarding loading, stability and controlled release of peptides from carriers. ${ }^{12-13}$

In this context, it would be advantageous to assemble functional peptides into nanoscale carriers. ${ }^{14-16}$ In addition to the high peptide loading, the resulting peptide nanoparticles would offer a range of potential benefits. For example, as the particles are assembled from bioactive peptides the amount of other constituent materials is reduced, thus lowering the risk of adverse side effects. Furthermore, the biodegradability of peptides ultimately reduces cumulative toxicity. Recently, peptide assemblies have been obtained by conjugation of amino acid sequences, hydrophobic chains, or polymers, ${ }^{16-19}$ improving delivery efficiency of pharmaceutical agents. However, engineering self-assembled peptide nanoparticles of a specific size that are stable under normal physiological conditions, but can disassemble under certain biological triggers, remains a challenge. ${ }^{16}$ Furthermore, irreversible coupling reactions reduce the bioactivity of peptides, ${ }^{20-23}$ highlighting the need for better disassembly strategies that yield native-state peptides. Combining peptide delivery with other therapeutics is often desired but requires additional functionalization or loading steps, which may hamper the activity of peptides and their self-assembly processes. ${ }^{16,17}$

Herein, we introduce a strategy to engineer functional peptide nanoparticles, using mesoporous silica nanoparticles (MSNs) as sacrificial templates (Scheme 1), and reversible chemistries engineered into the peptide network (Scheme 2). Our approach has distinct advantages in: (i) template assembly allows the facile engineering of peptide nanoparticles with defined sizes ${ }^{24-26}$; (ii) small molecule drugs can be loaded without hampering the assembly process; (iii) the disassembly and drug release properties can be tuned through the cross-linking chemistry; and (iv) the reversible functionality allows regeneration of pristine peptides and small molecule drugs by a biological trigger, endowing peptide nanoparticles with tunable bioactivity.

To achieve the triggered disassembly and subsequent peptide release, we chose disulfide-based chemistry to stabilize peptide nanoparticles. Disulfide-based chemistry has been extensively studied for controlled drug release 


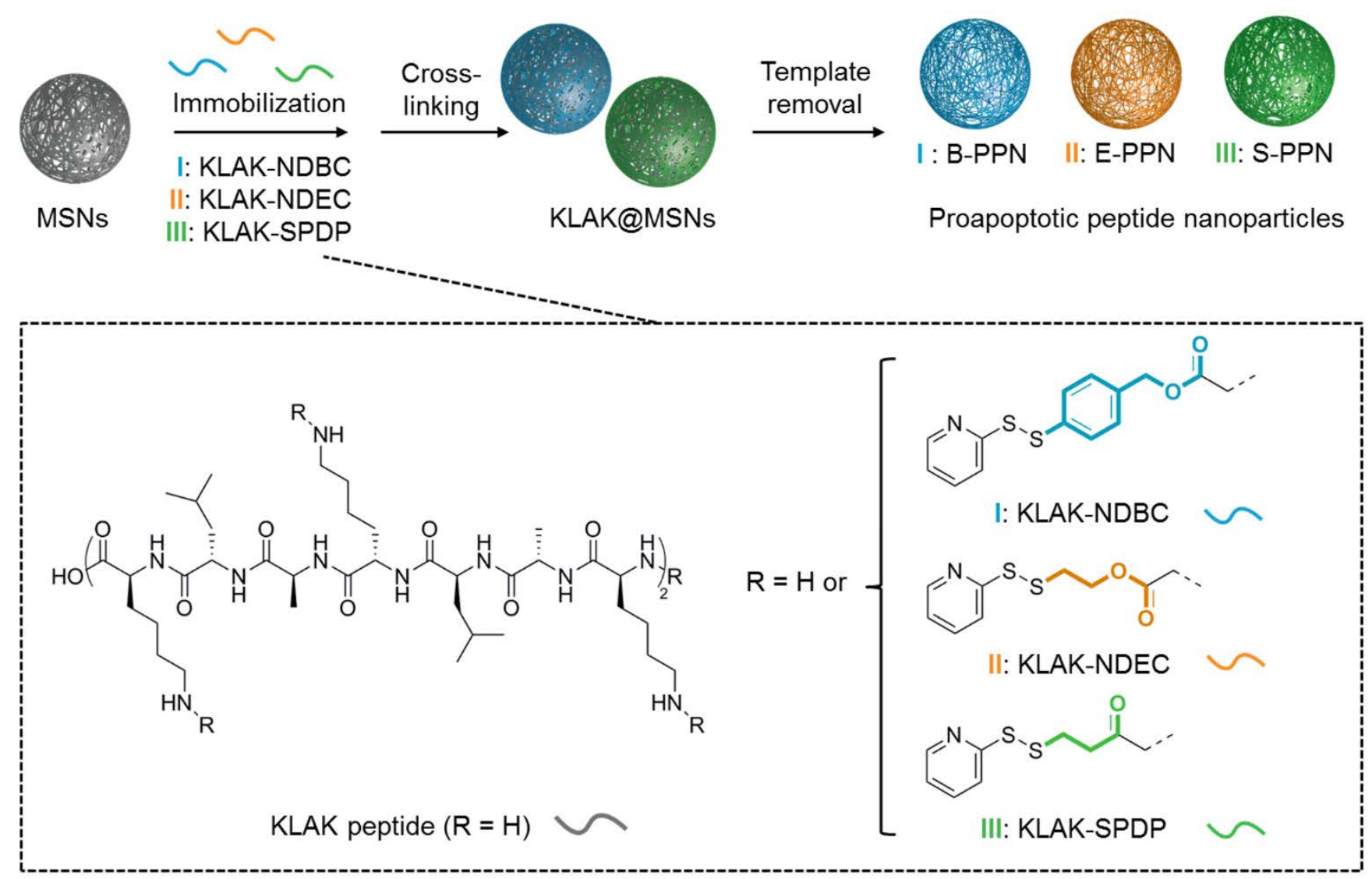

Scheme 1. Preparation of PPNs using template assembly. KLAK peptides modified with three different disulfide-introducing reagents (i.e., 4-nitrophenyl 4-(2-pyridyldithio)benzyl carbonate (NDBC), 4-nitrophenyl 2-(2-pyridyldithio)ethyl carbonate (NDEC), or succinimidyl 3-(2-pyridyldithio)propionate (SPDP)) were immobilized onto mesoporous silica nanoparticles (MSNs), followed by cross-linking with 8-arm-PEG-SH and template removal, resulting in proapoptotic peptide nanoparticles (i.e., B-PPN, E-PPN, or S-PPN, respectively).

within intracellular ${ }^{27,28}$ and tumor environments ${ }^{29}$ that have the elevated chemical reducing potential. However, when conventional conjugation reagents, such as succinimidyl 3(2-pyridyldithio)propionate $\quad(\text { SPDP })^{30} \quad$ or dithiobis(succinimidyl propionate), are used,,$^{31}$ molecular pendant groups remain on the peptides even after cleavage of the disulfide bond (Scheme 2c). Furthermore, the presence of such pendant groups reduces the bioactivity of the peptides. $^{21-23,32}$ In this regard, reversible disulfide chemistry, such as 4-dithiobenzyl urethane $(4 \text {-DBU })^{22,33,34}$ or $2^{-}$ mercaptoethyl urethane (2-DEU), ${ }^{31,35}$ undergo complete removal from peptides after the cleavage of disulfide bonds, ultimately regenerating unmodified amino groups (Scheme $2 \mathrm{a}$ and $\mathrm{b}$ ). Such reversibility in disulfide bond cleavage has not been studied for nanoparticles in mammalian cells, to our knowledge.

Herein, we study the effect of disulfide bond cleavage on the disassembly and drug release properties of peptide nanoparticles, leading to the development of new nanoparticles with modulated functionalities. These studies will provide useful information on the design of environment-sensitive functionalities for future biomedical applications, such as prodrug, ${ }^{36}$ PEGylation of proteins, ${ }^{22,23,32}$ cross-linking protein particles, ${ }^{31,37}$ latent fluorophores, ${ }^{35}$ reversible activation of endosomolytic agents, ${ }^{38,39}$ and signal amplification for ultrasensitive detection. ${ }^{40}$
In this study, functional peptide particles mainly composed of KLAK peptides, referred to herein as proapoptotic peptide nanoparticles (PPNs), were prepared (Scheme 1). A cationic amphipathic peptide, (KLAKLAK) (referred to herein as KLAK) is of interest for application in cancer therapy, because of the selective disruption of mitochondrial membranes, and thereby apoptosis of mammalian cells. $^{41,42}$ To improve the stability and internalization into cancer cells, KLAK peptides have been encapsulated into liposomes, ${ }^{43}$ conjugated onto iron oxide nanoparticles, ${ }^{44}$ chemically modified and assembled into nanoparticles, ${ }^{19,45}$ or complexed with polyelectrolytes. ${ }^{46}$ However, engineering of the nanoparticles with tunable geometry, disassembly, and therefore cytotoxicity has been a challenge. Herein, we present KLAK particles with apoptosispromoting capabilities programmed by tunable fragmentation kinetics, which are potentially useful for anticancer drug delivery. To tune the triggered disassembly of PPNs and the release of native bioactive peptides, three disulfide-based reversible cross-linking strategies were compared (Scheme 2). Interestingly, a marked difference in the cytotoxicity of PPNs from the three different reversible disulfide linkages was observed. To investigate the underlying mechanism, cellular association, particle disassembly, and disulfide cleavage mechanisms were studied with a focus on the different disulfide bonds. Furthermore, the potential of PPNs in therapeutic delivery 
applications was examined using a model anticancer drug, doxorubicin hydrochloride (DOX). Additionally, the effect of conjugation chemistry on the cytotoxic potency of the DOXloaded PPNs was evaluated. The present study provides a framework to exploit reversible chemistry to tune the therapeutic potency of PPNs and cargo and furthermore demonstrates that PPNs may be a promising platform for future application in nanomedicine.

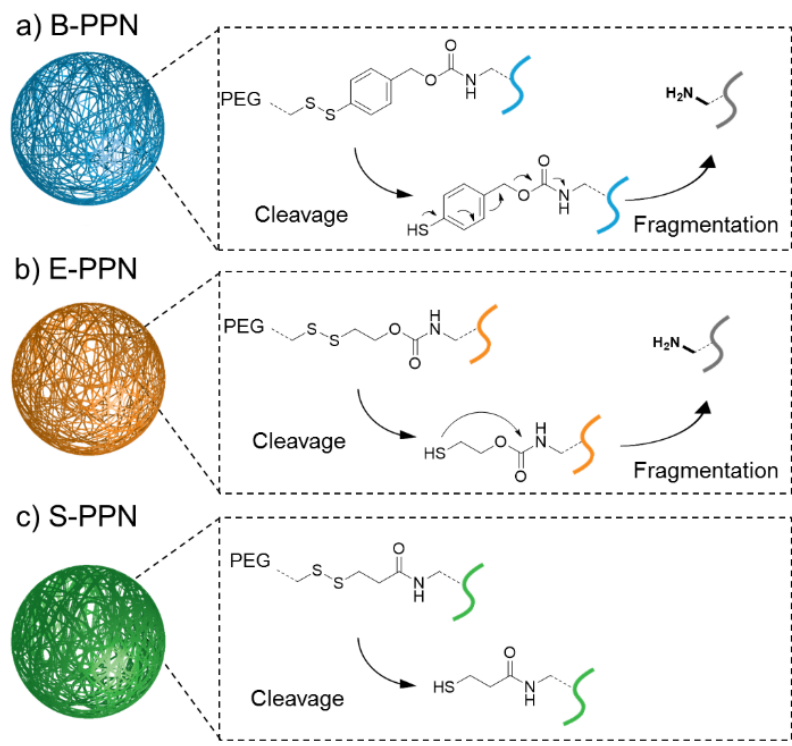

Scheme 2. Proposed mechanism of disulfide cleavage and fragmentation of (a) 4-dithiobenzyl urethane of B-PPN, (b) 2-dithioethyl urethane of E-PPN, and (c) 3-dithiopropyl amide of S-PPN.

\section{EXPERIMENTAL SECTION}

Materials. 2-Mercaptoethanol, 3-mercaptopropionic acid, 4-mercaptobenzoic acid, lithium aluminum hydride $\left(\mathrm{LiAlH}_{4}\right)$, $\mathrm{N}$-hydroxysuccinimide (NHS), 4-nitrophenyl chloroformate, $N, N^{\prime}$-dicyclohexylcarbodiimide (DCC), reduced L-glutathione (GSH), tetraethyl orthosilicate (TEOS), cetyltrimethylammonium tosylate (CTAT), triethanolamine, ammonia solution (28-30\%), hydrofluoric acid (HF), ammonium fluoride $\left(\mathrm{NH}_{4} \mathrm{~F}\right)$, triethylamine (TEA), 4(dimethylamino)pyridine (DMAP), $\quad \alpha$-cyano-4hydroxycinnamic acid, 3-(N-morpholino)propanesulfonic acid (MOPS), anhydrous dimethyl sulfoxide (DMSO), anhydrous pyridine, and anhydrous dichloromethane $\left(\mathrm{CH}_{2} \mathrm{Cl}_{2}\right)$ were purchased from Sigma-Aldrich (MO, USA). 2,2'-Dithiodipyridine and anhydrous tetrahydrofuran (THF) were obtained from Alfa Aesar (MA, USA). 8-Armpoly(ethylene glycol)-thiol (8-arm-PEG-SH) $\left(M_{\mathrm{w}}\right.$ : $\left.10 \mathrm{kDa}\right)$ was purchased from JenKem Technology (Beijing, China). Alexa Fluor 488 succinimidyl ester (AF-488-NHS), Alexa Fluor 568 succinimidyl ester (AF-568-NHS), an Alexa Fluor 488 annexin V/dead cell apoptosis kit, Hoechst 33342, and 2,3bis[2-methoxy-4-nitro-5-sulfophenyl]-2H-tetrazolium-5carboxyanilide inner salt (XTT) were purchased from Life Technologies (CA, USA). KLAK peptide (HOOCKLAKLAKKLAKLAK-NH $\mathrm{N}_{2}$ ) was obtained from GL Biochem (Shanghai, China). DOX was purchased from OChem Inc. (IL, USA). All chemicals were used as received without further purification. High-purity water with a resistivity of greater than 18.2 $\mathrm{M} \Omega \mathrm{cm}$ was obtained from a three-stage Millipore
Milli-Q plus 185 purification system (Millipore Corporation, MA, USA).

Synthesis of 4-Nitrophenyl 4-(2-Pyridyldithio)benzyl Carbonate (NDBC). NDBC was synthesized following a reported method (Supporting Information, Scheme $\left.\mathrm{S}_{1}\right) .^{36}$ To a suspension of $\mathrm{LiAlH}_{4}(0.74 \mathrm{~g}, 19.5 \mathrm{mmol})$ in anhydrous THF (10 mL), 4-mercaptobenzoic acid (1.0 g, $6.5 \mathrm{mmol}$ ) in anhydrous THF (10 mL) was slowly added at o ${ }^{\circ} \mathrm{C}$. After overnight stirring, the reaction was quenched by the addition of water $(500 \mu \mathrm{L})$. The $\mathrm{pH}$ of the mixture was adjusted to 2 by the addition of $2 \mathrm{~N} \mathrm{HCl}$ (aqueous; $~ 30 \mathrm{~mL}$ ), followed by extraction with ethyl acetate. The mixture was washed with water and brine, and dried over $\mathrm{MgSO}_{4}$. The product was purified by silica gel chromatography (ethyl acetate/hexane $=$ $\left.1 / 2(\mathrm{v} / \mathrm{v}), R_{\mathrm{f}}=0.30\right)$ to obtain 4-mercaptobenzyl alcohol as a white powder (yield: $559 \mathrm{mg}, 62 \%) .{ }^{1} \mathrm{H}$ NMR (40o MHz, $\mathrm{D}_{2} \mathrm{O}$, $\left.25{ }^{\circ} \mathrm{C}, \delta\right): 7.22(\mathrm{~d}, 2 \mathrm{H}), 7.15(\mathrm{~d}, 2 \mathrm{H}), 4.42$ (s, 2H) (Supporting Information, Figure $\mathrm{S} 1) .{ }^{13} \mathrm{C}$ NMR (10o $\left.\mathrm{MHz}, \mathrm{CDCl}_{3}, 2{ }^{\circ} \mathrm{C}, \delta\right)$ : 138.4, 130.2, 130.0, 129.6, 127.8, 127.5, 64.8 (Supporting Information, Figure S2).

4-Mercaptobenzyl alcohol (140 $\mathrm{mg}, 1 \mathrm{mmol}$ ) was dissolved in $\mathrm{CH}_{2} \mathrm{Cl}_{2}(0.75 \mathrm{~mL})$ and mixed with a solution of 2,2'dithiodipyridine (220 mg, $2 \mathrm{mmol}$ ) in $\mathrm{CH}_{2} \mathrm{Cl}_{2}(0.75 \mathrm{~mL})$. After overnight stirring, the excess solvent was removed by evaporation, followed by purification by silica gel chromatography (ethyl acetate/hexane $\left.=1 / 1(\mathrm{v} / \mathrm{v}), R_{\mathrm{f}}=0.35\right)$. After drying under reduced pressure, 4-(2pyridyldithio)benzyl alcohol was obtained as a pale yellow oil (yield: $183.2 \mathrm{mg}, 74 \%) .{ }^{1} \mathrm{H} \mathrm{NMR}\left(400 \mathrm{MHz}, \mathrm{CDCl}_{3}, 25^{\circ} \mathrm{C}\right): 8.45$ $(\mathrm{d}, 1 \mathrm{H}), 7.61(\mathrm{~m}, 2 \mathrm{H}), 7.50(\mathrm{~d}, 2 \mathrm{H}), 7.30(\mathrm{~d}, 2 \mathrm{H}), 7.08(\mathrm{~m}, 1 \mathrm{H})$, $4.65(\mathrm{~d}, 2 \mathrm{H})$ (Supporting Information, Figure $\left.\mathrm{S}_{3}\right) \cdot{ }^{13} \mathrm{C}$ NMR (100 $\mathrm{MHz}_{1} \mathrm{CDCl}_{3}, 25{ }^{\circ} \mathrm{C}, \delta$ ): 159.4, 148.6, 138.1, 130.4, 129.7, 129.6, 127.9, 121.0, 120.0, 64.6 (Supporting Information, Figure $\left.\mathrm{S}_{4}\right)$.

4-(2-Pyridyldithio)benzyl alcohol (170 $\mathrm{mg}, 0.7 \mathrm{mmol}$ ) was dissolved in anhydrous $\mathrm{CH}_{2} \mathrm{Cl}_{2}(5 \mathrm{~mL})$, which was added to a solution containing 4-nitrophenyl chloroformate (282 mg, 1.4 mmol), pyridine (111 $\mathrm{mg}, 1.4 \mathrm{mmol}$ ), and a catalytic amount of DMAP in anhydrous $\mathrm{CH}_{2} \mathrm{Cl}_{2}(5 \mathrm{~mL})$. After overnight stirring, the reaction mixture was washed with $2 \mathrm{~N} \mathrm{HCl}$ (aqueous) and brine, and dried over $\mathrm{MgSO}_{4}$. After removal of excess solvent by evaporation, the product was purified by silica gel chromatography (ethyl acetate/hexane $=1 / 4(\mathrm{v} / \mathrm{v}), R_{\mathrm{f}}=0.23$ ) to obtain 4-nitrophenyl 4-(2-pyridyldithio)benzyl carbonate as a pale yellow solid (yield: $229.3 \mathrm{mg}, 81 \%$ ). ${ }^{1} \mathrm{H}$ NMR (400 $\left.\mathrm{MHz}, \mathrm{CDCl}_{3}, 25^{\circ} \mathrm{C}, \delta\right): 8.49(\mathrm{~d}, 1 \mathrm{H}), 8.26(\mathrm{~d}, 2 \mathrm{H}), 7.61(\mathrm{~d}, 2 \mathrm{H})$, $7.55(\mathrm{~d}, 2 \mathrm{H}), 7.40-7.32(\mathrm{~m}, 4 \mathrm{H}), 7.20(\mathrm{~m}, 1 \mathrm{H}), 5.22(\mathrm{~s}, 2 \mathrm{H})$ (Supporting Information, Figure $\left.\mathrm{S}_{5}\right) .{ }^{13} \mathrm{C} \mathrm{NMR}(100 \mathrm{MHz}$, $\mathrm{CDCl}_{3}, 25{ }^{\circ} \mathrm{C}, \delta$ ): 159.0, 155.4, 152.3, 148.9, 145.4, 138.0, 137.1, $133.4,129.5,127.5,125.2,121.7,121.2,120.0,70.2$ (Supporting Information, Figure S6).

Synthesis of 4-Nitrophenyl 2-(2-Pyridyldithio)ethyl Carbonate (NDEC). 2,2'-Dithiodipyridine ( $880 \mathrm{mg}, 4.0$ mmol) was dissolved in $\mathrm{CH}_{2} \mathrm{Cl}_{2}$, and 2-mercaptoethanol (313 $\mathrm{mg}$, $4.0 \mathrm{mmol}$ ) was added. After $2 \mathrm{~h}$ of stirring, the excess solvent was removed, followed by purification with silica gel chromatography (ethyl acetate/hexane $\left.=1 / 3(\mathrm{v} / \mathrm{v}), R_{\mathrm{f}}=0.4\right)$ to obtain 2-(2-pyridyldithio)ethyl alcohol as a pale yellow liquid (yield: $400 \mathrm{mg}, 53 \%) .{ }^{1} \mathrm{H}$ NMR (400 $\mathrm{MHz} \mathrm{CDCl}_{3}, 25{ }^{\circ} \mathrm{C}, \delta$ ): $8.49(\mathrm{~d}, 1 \mathrm{H}), 7.56(\mathrm{t}, 1 \mathrm{H}), 7.38(\mathrm{~d}, 1 \mathrm{H}), 7.15^{-7.11}(\mathrm{~m}, 1 \mathrm{H}), 5.70(\mathrm{~s}$, $1 \mathrm{H}), 3.78(\mathrm{~s}, 2 \mathrm{H}), 2.94(\mathrm{t}, 2 \mathrm{H})$ (Supporting Information, Figure 
$\left.\mathrm{S}_{7}\right) .{ }^{13} \mathrm{C}$ NMR (10o $\mathrm{MHz}, \mathrm{CDCl}_{3}, 25{ }^{\circ} \mathrm{C}, \delta$ ): 159.1, 149.8, 136.8, 121.9, 121.5, 58.2, 42.7 (Supporting Information, Figure S8).

2-(2-Pyridyldithio)ethyl alcohol (187 mg, 1.0 mmol) was dissolved in anhydrous $\mathrm{CH}_{2} \mathrm{Cl}_{2}(10 \mathrm{~mL})$, to which anhydrous pyridine ( $158 \mathrm{mg}, 2 \mathrm{mmol}$ ) and a catalytic amount of DMAP were added. Then, 4-nitrophenyl chloroformate (403 mg, 2.0 mmol) was added, and the reaction mixture was stirred overnight. The mixture was washed with $2 \mathrm{~N} \mathrm{HCl}$ (aqueous) and brine, followed by drying over $\mathrm{MgSO}_{4}$. After excess solvent was removed by evaporation, silica gel chromatography (hexane/ethyl acetate $\left.=1 / 3(\mathrm{v} / \mathrm{v}), R_{\mathrm{f}}=0.24\right)$ was conducted to obtain 4-nitrophenyl 2-(2pyridyldithio)ethyl carbonate as a pale yellow oil (yield: 193.5 mg, 55\%). ${ }^{1} \mathrm{H}$ NMR (40o $\left.\mathrm{MHz}, \mathrm{CDCl}_{3}, 25{ }^{\circ} \mathrm{C}, \delta\right): 8.53(\mathrm{~d}, \mathrm{H})$, $8.27(\mathrm{~d}, 2 \mathrm{H}), 7.72(\mathrm{~d}, 2 \mathrm{H}), 7.36(\mathrm{~d}, 2 \mathrm{H}), 7.21-7.16(\mathrm{~m}, 1 \mathrm{H}), 4.55$ $(\mathrm{t}, 2 \mathrm{H}), 3.17(\mathrm{t}, 2 \mathrm{H})$ (Supporting Information, Figure $\mathrm{S} 9) .{ }^{13} \mathrm{C}$ NMR (100 $\mathrm{MHz}, \mathrm{CDCl}_{3}, 25{ }^{\circ} \mathrm{C}, \delta$ ): $158.7,155.3,152.2,148.4$, $145.5,138.6,125.3,121.7,121.5,121.1,66.5,37.0$ (Supporting Information, Figure S10).

Synthesis of Succinimidyl 3-(2-Pyridyldithio) Propionate (SPDP). SPDP was synthesized following a reported method (Supporting Information, Scheme $\mathrm{S} 1) .^{30}$ 2,2'-Dithiodipyridine $(2.2 \mathrm{~g}, 9.96 \mathrm{mmol})$ was dissolved in ethanol (16 mL), to which acetic acid (0.3 mL) and 3mercaptopropionic acid (0.528 g, $4.98 \mathrm{mmol}$ ) were added. After $2 \mathrm{~h}$ of stirring, ethanol and acetic acid were removed by evaporation. Then, the resultant pale yellow oil was purified through a basic $\mathrm{Al}_{2} \mathrm{O}_{3}$ column. First, $\mathrm{CH}_{2} \mathrm{Cl}_{2}$ /ethanol = 3/2 $(\mathrm{v} / \mathrm{v})$ was flushed through the oil-containing $\mathrm{Al}_{2} \mathrm{O}_{3}$ column until a colorless filtrate was obtained. Then, $\mathrm{CH}_{2} \mathrm{Cl}_{2} /$ ethanol/acetic acid $=6 \mathrm{o} / 4 \mathrm{O} / 4(\mathrm{v} / \mathrm{v} / \mathrm{v})$ was flushed to elute the desired product. The solvents were removed by evaporation to obtain 3-(2-pyridyldithio)propionic acid as a pale yellow oil (yield: $745.8 \mathrm{mg}, 70 \%) .{ }^{1} \mathrm{H}$ NMR $(400 \mathrm{MHz}$, $\left.\mathrm{CDCl}_{3}, 2{ }^{\circ} \mathrm{C}, \delta\right): 8.50(\mathrm{~d}, 1 \mathrm{H}), 7.75^{-7} .66(\mathrm{~m}, 2 \mathrm{H}), 7.20(\mathrm{t}, 1 \mathrm{H})$, $3.06(t, 2 \mathrm{H}), 2.79(\mathrm{t}, 2 \mathrm{H})$ (Supporting Information, Figure S11). ${ }^{13} \mathrm{C}$ NMR (10o $\mathrm{MHz}, \mathrm{CDCl}_{3}, 25{ }^{\circ} \mathrm{C}, \delta$ ): 175.1, 159.0, 148.6, 138.2, 121.5, 121.1, 34.1 (2C) (Supporting Information, Figure S12).

3-(2-Pyridyldithio)propionic acid (690 mg, $3.2 \mathrm{mmol}$ ) was dissolved in anhydrous $\mathrm{CH}_{2} \mathrm{Cl}_{2}$, and then NHS (440 mg, 3.8 $\mathrm{mmol}$ ) and DCC (784 mg, $3.8 \mathrm{mmol}$ ) were added. After $3 \mathrm{~h}$ of stirring, the precipitate was removed by filtration, and the solvent was removed by evaporation. After reconstitution in $\mathrm{CH}_{2} \mathrm{Cl}_{2}$, the undissolved portion was removed by filtration. The excess solvent was removed, and the product was crystallized in ethanol at $-20{ }^{\circ} \mathrm{C}$. The obtained crystals were dissolved in $\mathrm{CH}_{2} \mathrm{Cl}_{2}$, followed by crystallization in isopropanol at $-20{ }^{\circ} \mathrm{C}$ to obtain SPDP as a white powder (yield: $649.5 \mathrm{mg}, 65 \%)$. ${ }^{1} \mathrm{H}$ NMR (40o $\mathrm{MHz}, \mathrm{CDCl}_{3}, 2{ }^{\circ} \mathrm{C}, \delta$ ): 8.51 (d, $1 \mathrm{H}), 7.74(\mathrm{~d}, 2 \mathrm{H}), 7.17(\mathrm{~m}, 1 \mathrm{H}), 3.14(\mathrm{t}, 2 \mathrm{H}), 3.06(\mathrm{t}, 2 \mathrm{H})$, $2.82(\mathrm{~s}, 4 \mathrm{H})$ (Supporting Information, Figure $\left.\mathrm{S}_{13}\right) \cdot{ }^{13} \mathrm{C}$ NMR (100 $\mathrm{MHz}, \mathrm{CDCl}_{3}, 25{ }^{\circ} \mathrm{C}, \delta$ ): 168.8, 166.9, 159.0, 148.6, 138.5, 121.3, 120.6, 33.0, 30.9, 25.6 (Supporting Information, Figure S14).

Preparation of MSNs. MSNs were prepared following a previously published method. ${ }^{47}$ Briefly, CTAT (96o mg) and triethanolamine $(174 \mathrm{mg})$ were dissolved in water $(50 \mathrm{~mL})$ at $80{ }^{\circ} \mathrm{C}$. Then, TEOS $(7.8 \mathrm{~mL})$ was quickly added to the above solution. The mixture was stirred at $80{ }^{\circ} \mathrm{C}$ for $2 \mathrm{~h}$. The synthesized MSNs were washed with water and ethanol, dried at $80^{\circ} \mathrm{C}$, and finally calcined at $550^{\circ} \mathrm{C}$ for $6 \mathrm{~h}$.
Preparation of PPNs. PPNs from NDBC chemistry (BPPNs) were prepared as follows. The MSNs were suspended in MOPS buffer ( $50 \mathrm{mM}, \mathrm{pH} 8.0$ ) at a concentration of $10 \mathrm{mg}$ $\mathrm{mL}^{-1}$. KLAK peptide was dissolved in anhydrous DMSO with $1 \%$ TEA at a concentration of $10 \mathrm{mg} \mathrm{mL}^{-1}$. To the solution containing KLAK peptide, a solution of NDBC $\left(100 \mathrm{mg} \mathrm{mL}^{-1}\right.$ in anhydrous DMSO) was added at a NDBC-to-KLAK molar ratio of 4 . After $2 \mathrm{~h}$ of incubation, the solution containing the NDBC-modified KLAK peptide $(60 \mu \mathrm{L})$ was mixed with the MSN suspension $(150 \mu \mathrm{L})$, followed by the addition of MOPS buffer $(700 \mu \mathrm{L}, 50 \mathrm{mM}, \mathrm{pH}$ 8.0). The suspension was incubated for $3 \mathrm{~min}$ and centrifuged at $1000 \mathrm{~g}$ for $3 \mathrm{~min}$, followed by removal of the supernatant and the addition of MOPS buffer $(700 \mu \mathrm{L}, 50 \mathrm{mM}, \mathrm{pH}$ 8.0). This process was repeated twice. Then, 8 -arm-PEG-SH in MOPS buffer $(50 \mu \mathrm{L}$, $50 \mathrm{mM}, \mathrm{pH}$ 8.o) was added at a -SH-to-NDBC molar ratio of 1.1:1. After $1 \mathrm{~h}$ of stirring, the suspension was centrifuged at $1000 \mathrm{~g}$ for $3 \mathrm{~min}$, followed by removal of the supernatant and the addition of MOPS buffer ( $700 \mu \mathrm{L}, 50 \mathrm{mM}, \mathrm{pH}$ 8.o). This process was repeated once. Finally, the MSN templates were removed using buffered $\mathrm{HF}$ solution (5 $\mathrm{M}$ HF/13.3 $\mathrm{M}$ $\mathrm{NH}_{4} \mathrm{~F} / \mathrm{H}_{2} \mathrm{O}=1 / 6 / 3$ ) (Caution! Hydrofluoric acid is highly toxic. Extreme care should be taken when handling HF solution, and only small quantities should be prepared), followed by three washing cycles with water. The obtained particles were dispersed by sonication and any aggregated particles were removed by centrifugation at $1000 \mathrm{~g}$ for $5 \mathrm{~min}$. The process was repeated twice to obtain dispersed particles. The S-PPNs and E-PPNs were prepared following a similar procedure, using SPDP and NDEC, respectively, instead of NDBC.

Determination of Peptide Concentration. The peptide concentration was determined by Lowry's method with a slight modification. ${ }^{48,49}$ Briefly, a solution containing an unknown concentration of PPNs (10 $\mu \mathrm{L})$ was mixed with a solution $(100 \mu \mathrm{L})$ of $0.2 \mathrm{M} \mathrm{NaOH}$ supplemented with $4 \%$ $\mathrm{Na}_{2} \mathrm{CO}_{3}, 2 \% \mathrm{CuSO}_{4}$, and $4 \%$ sodium tartrate at a volume ratio of 100:1:1, followed by 10 min of incubation. Then, 2 M FolinCiocalteu's phenol reagent ( $10 \mu \mathrm{L})$ was added, followed by 20 min of incubation. The absorbance at $750 \mathrm{~nm}$ was measured using an Infinite M2oo microplate reader (Tecan, Switzerland). The absorbance at $750 \mathrm{~nm}$ in the absence of $\mathrm{CuSO}_{4}$ was used as background (disulfides and sulfhydryls are known to interfere with Lowry's method). ${ }^{49}$ The concentration of peptide was calculated from a calibration curve obtained using peptide solutions with known concentrations.

Zetasizer Measurements. The hydrodynamic diameter, scattering light intensity (SLI), and zeta( $\zeta$ )-potential of the particles were measured using a Zetasizer Nano ZS instrument (Malvern Instruments, Malvern, UK) equipped with a He-Ne ion laser $(\lambda=633 \mathrm{~nm})$ as an incident beam. For the dynamic light scattering (DLS) measurements, a particle dispersion in phosphate buffer $(\mathrm{pH} 7.4,10 \mathrm{mM})(60 \mu \mathrm{L})$ was placed in a micro cuvette (ZENoo4o, Malvern Instruments). The photon correlation function was analyzed by the cumulant method to derive the diffusion coefficients $\left(D_{\mathrm{C}}\right)$ of the particles. The obtained $D_{\mathrm{C}}$ was converted into the hydrodynamic diameter $\left(D_{\mathrm{H}}\right)$ using the Stokes-Einstein equation: $D_{\mathrm{H}}=k_{\mathrm{B}} T / 3 \pi \eta D_{\mathrm{C}}\left(k_{\mathrm{B}}\right.$ : Boltzmann constant, $T$ : absolute temperature, $\eta$ : viscosity of the solvent). For the $\zeta$ potential measurements, a particle dispersion in phosphate buffer $(\mathrm{pH} 7.4,10 \mathrm{mM})(800 \mu \mathrm{L})$ was placed into a folded 
capillary cell (DTS1070, Malvern Instruments). The $\zeta$ potential was obtained from the electrophoretic mobility and by using the Smoluchowski equation: $\zeta=4 \pi \eta v / \varepsilon$ ( $\eta$ : viscosity of the solvent, $v$ : electrophoretic mobility, $\varepsilon$ : dielectric constant of the solvent).

Transmission Electron Microscopy (TEM). A suspension containing the PPNs or MSNs was casted on Formvar-coated copper grids, followed by overnight airdrying. The grids were then washed with pure water to remove salt and allowed to dry in air. TEM imaging was conducted on a CMro BioTWIN instrument (Philips, Germany) operating at an acceleration voltage of $120 \mathrm{kV}$.

Matrix-Assisted Laser Desorption/Ionization Time-ofFlight Mass Spectrometry (MALDI-ToF MS). The PPNs were incubated in phosphate buffer ( $\mathrm{pH} 7.4,10 \mathrm{mM})$ containing $5 \mathrm{mM} \mathrm{GSH}$. After incubation for either 2 or $24 \mathrm{~h}$, the dispersions were centrifuged (80oo $\mathrm{g}, 3 \mathrm{~min}$ ). The supernatant was collected and mixed with a solution of $\alpha$ cyano-4-hydroxycinnamic acid (10 $\mathrm{mg} \mathrm{mL}^{-1}$ ) in a $1 / 1(\mathrm{v} / \mathrm{v})$ water/acetonitrile mixture containing $0.1 \%$ trifluoroacetic acid. MALDI-ToF MS measurements were subsequently performed (Autoflex, Bruker, MA, USA).

KLAK Peptide Release Study. The PPNs were prepared from KLAK peptides labeled with AF-568. The PPNs $(250 \mu \mathrm{L}$, $1000 \mu \mathrm{g} \mathrm{mL} \mathrm{m}^{-1}$ of KLAK) were dialyzed against phosphate buffer (10 mL, pH 7.4, $20 \mathrm{mM}$ ) containing either $5 \mathrm{mM}$ or 10 $\mu \mathrm{M}$ GSH using a dialysis membrane with a molecular weight cut-off of $7000 \mathrm{Da}$. At each time point, the solution outside the dialysis membrane $(500 \mu \mathrm{L})$ was withdrawn and replaced with the same volume of fresh buffer containing GSH. The KLAK peptide concentration in the solution was determined based on the fluorescence of AF-568, which was measured using an Infinite M20o microplate reader.

Preparation of DOX-Loaded PPNs. The DOX-loaded PPNs were prepared following a similar procedure. The DOX was dissolved in anhydrous DMSO with $1 \%$ TEA at a concentration of $10 \mathrm{mg} \mathrm{mL}^{-1}$. To this solution, NDBC (100 mg $\mathrm{mL}^{-1}$ in anhydrous DMSO) was added at a NDBC-to-DOX molar ratio of 1.1:1, followed by $2 \mathrm{~h}$ of incubation. A desired amount of this solution was then mixed with a NDBCmodified KLAK peptide solution prior to immobilization into MSNs. Following immobilization, the particles were washed twice with MOPS buffer (50 mM, pH 8.0). Then, 8-arm-PEG$\mathrm{SH}$ in MOPS buffer (50 mM, pH 8.o) was added at a -SH-toNDBC molar ratio of 1.1:1. The MSN templates were then removed following the same procedure as that described for preparing PPNs in the absence of DOX loading. To determine the composition, the PPNs were prepared from AF-633-labeled KLAK peptides. The KLAK peptides and DOX concentration were determined by fluorescence spectrophotometry and UV-visible spectrophotometry (NanoDrop 20oo, Thermo Fisher Scientific, MA, USA).

DOX Release Studies. The DOX-loaded PPNs (300 $\mu \mathrm{L}$, $250 \mu \mathrm{g} \mathrm{mL} \mathrm{m}^{-1}$ of DOX) were dialyzed against phosphate buffer (10 mL, pH 7.4, $20 \mathrm{mM}$ ) containing either $5 \mathrm{mM}$ or $10 \mu \mathrm{M}$ GSH using a dialysis membrane with a molecular weight cutoff of 7000 Da. At each time point, the solution outside the dialysis membrane $(500 \mu \mathrm{L})$ was withdrawn and replaced with the same volume of fresh buffer containing GSH. The DOX concentration in the solution was determined based on fluorescence from DOX, which was obtained using an Infinite M20o microplate reader.

Cell Viability Assays. HeLa cells were plated on a 96-well plate (Costar 3596, Corning, MA, USA) at a cell density of 5000 cells per well in cell culture media $(100 \mu \mathrm{L})$, followed by incubation for $24 \mathrm{~h}$. The PPNs, free KLAK peptides, DOXloaded PPNs, and free DOX were added at varying concentrations of KLAK peptides or DOX. After $48 \mathrm{~h}$ of incubation, the cell viability was evaluated by an XTT assay. The absorbances at 475 and $650 \mathrm{~nm}$, used as references, were recorded using an Infinite Mzoo microplate reader. The cell viability was calculated as a ratio against the absorbance obtained from non-treated cells.

Annexin V/Propidium Iodide (PI) Assays. HeLa cells were plated on Nunc ${ }^{\mathrm{TM}}$ Lab-Tek $^{\mathrm{TM}}$ II 8-well-chambered coverglass slides at a cell density of 10 ooo cells per well in cell culture media $(200 \mu \mathrm{L})$. After $24 \mathrm{~h}$ of incubation, the PPNs were added at a KLAK concentration of $20 \mu \mathrm{M}$. After 24 $\mathrm{h}$ of incubation, the cells were stained with a dead cell apoptosis kit with annexin V-AF-488 and PI (Thermo Fisher Scientific, MA, USA) following the manufacturer's protocol. Fluorescence microscopy images were taken using an Olympus $\mathrm{IX}_{71}$ inverted fluorescence microscope (Olympus, Japan) equipped with a $40 \times$ objective.

Flow Cytometry. HeLa cells were plated on a 96-well plate at a cell density of 5000 cells per well in cell culture media $(100 \mu \mathrm{L})$. After $24 \mathrm{~h}$ of incubation, the PPNs were added at a KLAK peptide concentration of $10 \mu \mathrm{M}$. At various time points, the medium was removed and the cells were washed with phosphate-buffered saline (PBS). After treatment with trypsin, the cells were suspended in ice-cold PBS, and flow cytometry analysis of the cells was conducted using an A5o Micro Flow Cytometer (Apogee Flow Systems, UK).

Deconvolution Microscopy. HeLa cells were plated on Nunc ${ }^{\mathrm{TM}}$ Lab-Tek $^{\mathrm{TM}}$ II 8-well-chambered coverglass slides at a cell density of 10 ooo cells per well in cell culture media (200 $\mu \mathrm{L}$ ), followed by $24 \mathrm{~h}$ of incubation. For the cellular internalization study, the PPNs were added at a concentration of $10 \mu \mathrm{M}$. After $10 \mathrm{~h}$ of incubation, deconvolution microscopy images were taken using a Delta Vision (Applied Precision) equipped with a $60 \times 1.42 \mathrm{NA}$ oil objective with a standard FITC/TRITC/Cy5 filter set. For analysis of the DOX-loaded PPNs, the particles were added at a DOX concentration of $2 \mu \mathrm{M}$. After $24 \mathrm{~h}$ of incubation, deconvolution microscopy images were taken.

\section{RESULTS AND DISCUSSION}

Preparation and Characterization of PPNs. PPNs were prepared using MSNs as templates (Scheme 1). Prior to immobilization on MSNs, KLAK peptides were modified with 2-pyridyldithio moieties by reaction with NDBC, NDEC, or SPDP. The latter three reagents were synthesized via disulfide exchange and activation (Supporting Information, Scheme $\mathrm{S} 1)$. Subsequent cross-linking by 8 -arm-PEG-SH $\left(M_{\mathrm{w}}\right.$ $\sim 10 \mathrm{kDa})$ through disulfide exchange and removal of the templates resulted in PPNs. Successful preparation of the PPNs was confirmed by DLS and TEM (Figure 1, Table 1). All three types of PPNs were well dispersed in aqueous solution and had a uniform size distribution with an average hydrodynamic diameter of $\sim 185 \mathrm{~nm}$ (Table 1 ). Compared with the MSN templates, which featured an average 
hydrodynamic diameter of $135 \pm 6 \mathrm{~nm}$, the PPNs were slightly larger, probably due to swelling, owing to the mobility of the PEG chains. The $\zeta$-potentials of the PPNs were close to neutral, with negligible variation across the three types of cross-linked particles. This result suggests that the PPNs made of KLAK peptides and PEG have comparable compositions (Table 1). Stability under physiological salt conditions is important for the biological application of peptide nanoparticles. As peptides are weakly charged polyelectrolytes of low molecular weight, the presence of high concentrations of salt may induce dissociation of the peptides from the nanoparticles unless they are covalently attached. Furthermore, electrostatic repulsion between nanoparticles is screened in high salt concentrations, which may result in unexpected nanoparticle aggregation. The $D_{\mathrm{H}}$ and polydispersity index (PDI) of the PPNs remained constant for at least $6 \mathrm{~h}$ of incubation (Supporting Information, Figure S15), thus demonstrating the stability of the PPNs under physiological salt conditions, probably because of the presence of PEG in the structure.
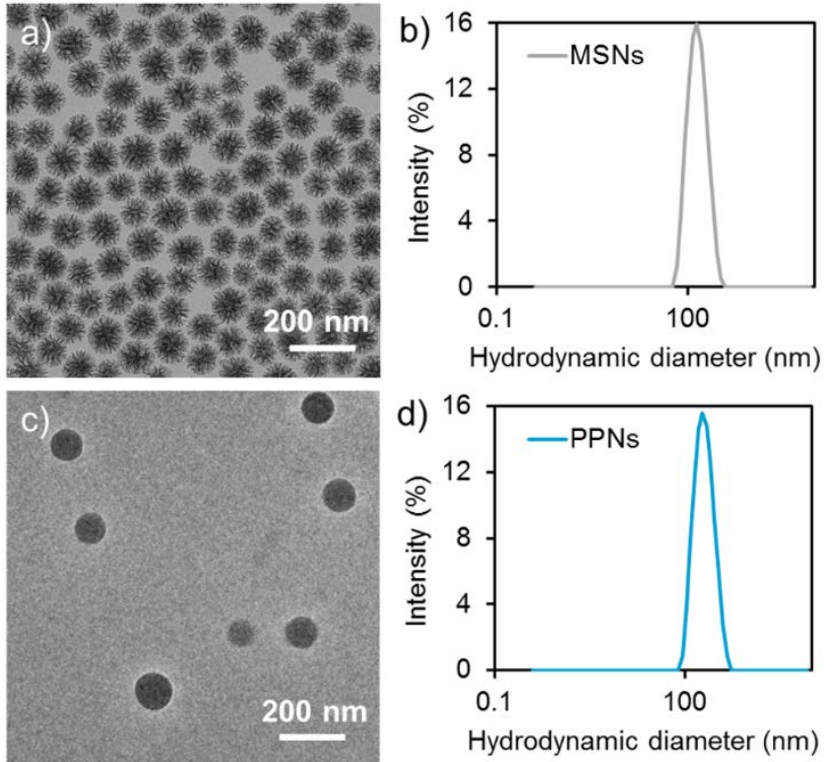

Hydrodynamic diameter $(\mathrm{nm})$

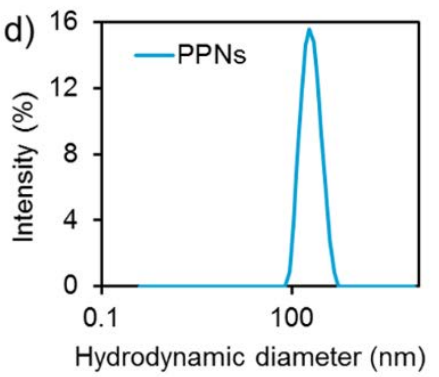

Figure 1. TEM images of (a) MSNs and (c) PPNs prepared using NDBC chemistry (B-PPN). Size distributions of (b) MSNs and (d) B-PPNs obtained by DLS.

Table 1. Physicochemical Properties of MSNs and PPNs Prepared from Three Different Disulfide Linkages

\begin{tabular}{lcccc}
\hline & Chemistry & $\begin{array}{c}\text { Size } \\
(\mathrm{nm})^{\mathrm{a}, \mathrm{b}}\end{array}$ & PDI $^{\mathrm{a}}$ & $\begin{array}{c}\zeta \text {-potential } \\
(\mathrm{mV})^{\mathrm{a}}\end{array}$ \\
\hline MSN & - & $135 \pm 6$ & $0.14 \pm 0.03$ & $-34 \pm 2$ \\
B-PPN & NDBC & $181 \pm 15$ & $0.16 \pm 0.04$ & $2 \pm 1$ \\
E-PPN & NDEC & $183 \pm 7$ & $0.17 \pm 0.02$ & $3 \pm 1$ \\
S-PPN & SPDP & $190 \pm 15$ & $0.14 \pm 0.03$ & $2 \pm 1$ \\
\hline
\end{tabular}

${ }^{\mathrm{a}}$ Determined in phosphate buffer $(\mathrm{pH} 7.4,10 \mathrm{mM})$. The results are expressed as the mean \pm standard deviation obtained from four samples. ${ }^{\mathrm{b}}$ Size stands for hydrodynamic diameter measured by DLS.

Cytotoxicity of PPNs against Cancer Cells. The cytotoxicity of PPNs against HeLa cells was examined by XTT assays (Figure 2a, Table $\mathrm{S}$ ). Treatment with PPNs prepared using reversible NDBC (B-PPN) or NPDE chemistry (E-PPN) significantly reduced cell viability. Furthermore, the cytotoxicity was higher than free KLAK peptides that showed cytotoxic effects consistent with previously reported results. ${ }^{50}$ The stronger cytotoxicity of the PPNs than KLAK peptides can be attributed to the efficient association of the PPNs with cells when compared with free peptides. In contrast, the PPNs prepared using non-reversible SPDP chemistry (S-PPN) resulted in a negligible reduction in cell viability, even at the highest concentration tested $(\sim 100 \mu \mathrm{M})$. Moreover, the S-PPN particles had a considerably lower cytotoxicity than free KLAK peptides. The minimal cytotoxicity of S-PPN suggested that cell death induced by BPPN and E-PPN was based on the reversible release of KLAK peptide in the cytoplasm, which could subsequently induce apoptosis. It is noted that B-PPN induced a greater reduction in cell viability when compared with E-PPN when the same equivalent of peptides was used even though both PPNs featured reversibility in the disulfide linkages.
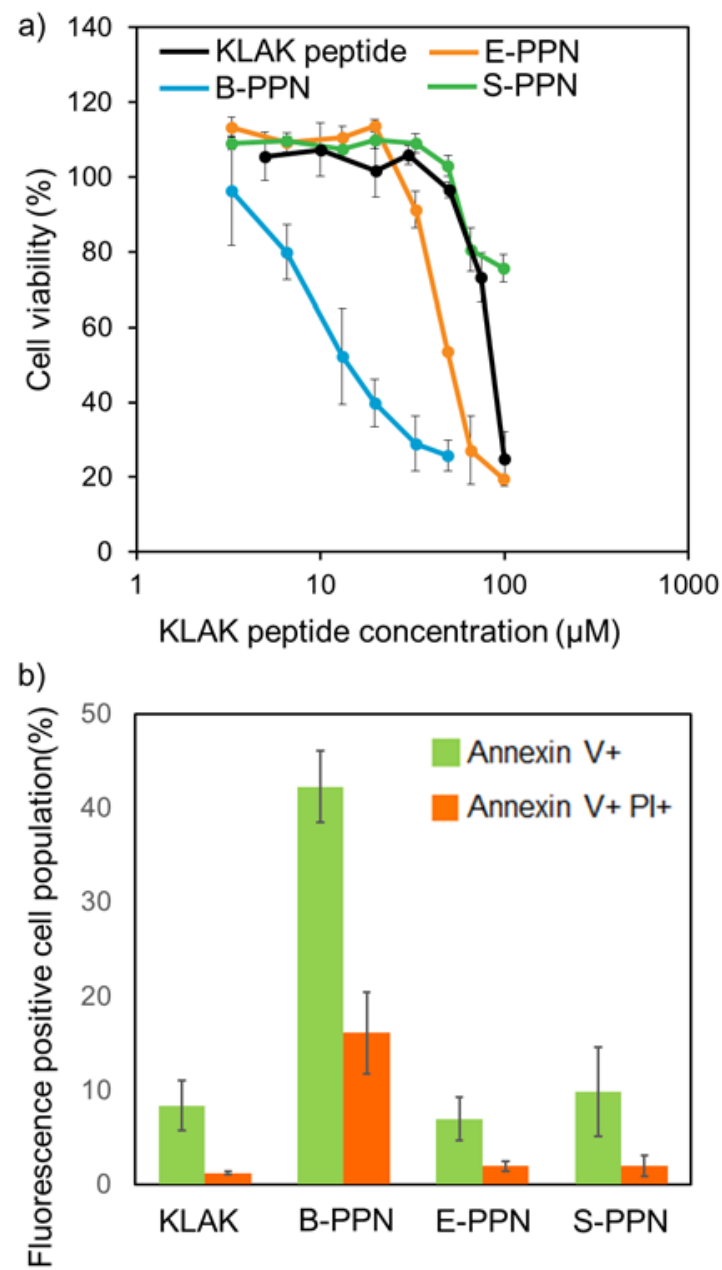

Figure 2. (a) Cell viability of HeLa cells after treatment with B-PPN, E-PPN, S-PPN, or free KLAK peptides for $48 \mathrm{~h}$, as determined by XTT assays. Error bars represent standard deviations of the means obtained from four samples. (b) Population of annexin $\mathrm{V}-\mathrm{AF}_{4} 88$ positive, and annexin $\mathrm{V}$ AF488 and PI positive cells after $24 \mathrm{~h}$ treatment with PPNs or free peptides at a KLAK concentration of $20 \mu \mathrm{M}$. Approximately 200 cells were analyzed for each sample. The 
results are expressed as means \pm standard deviations obtained from three samples.

Next, to examine the activation of apoptotic processes, the cells were stained with annexin V-AF-488 and PI after treatment for $24 \mathrm{~h}$ with either the PPNs or free peptides at a KLAK concentration of $20 \mu \mathrm{M}$ (Figure 2b, Supporting Information, Figure S16). Treatment with B-PPN resulted in $\sim 26 \%$ of the cell populations stained with annexin $\mathrm{V}-\mathrm{AF}_{4} 88$ but not with PI. These results suggest the onset of apoptosis in the cells. In contrast, the population of such cells (annexin V-positive, PI-negative) was limited to $5-7 \%$ when the cells were treated with E-PPN, S-PPN, or free KLAK peptides, suggesting that apoptosis is not induced under the conditions tested (consistent with the XTT assay). Furthermore, the results suggest that cell death induced by PPN was based on induction of apoptosis, probably due to the reversible release of peptides in the cytoplasm. However, significant differences in the cell-killing efficiency were observed between the two reversibly cross-linked nanoparticles, i.e., B-PPN and E-PPN. We therefore investigated the disassembly profile, cellular association, and intracellular behavior of these two peptide nanoparticle systems.
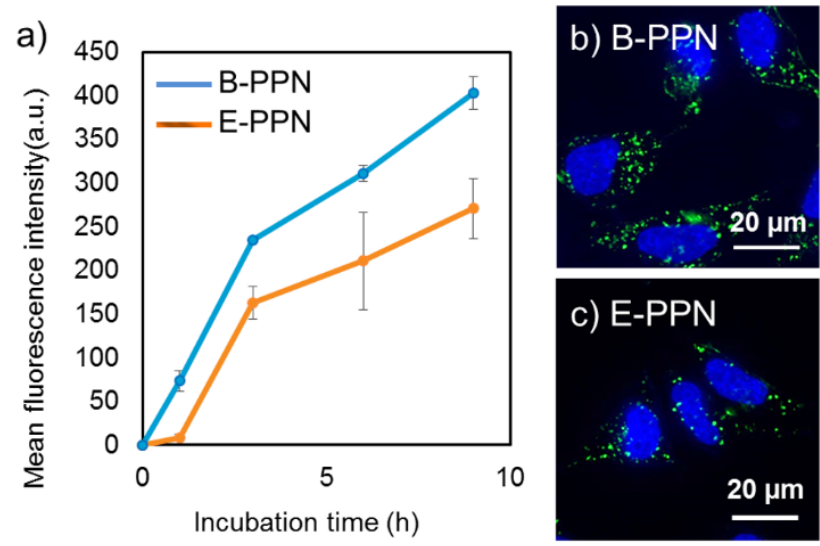

Figure 3. (a) Transition of mean fluorescence intensity from HeLa cells treated with either AF-488-labeled B-PPN or EPPN at a peptide concentration of $10 \mu \mathrm{M}$, which was measured by flow cytometry. Error bars represent standard deviations of the means obtained from three samples. Deconvolution microscopy images of HeLa cells treated with either (b) B-PPN or (c) E-PPN at a peptide concentration of 10 $\mu \mathrm{M}$ for $10 \mathrm{~h}$. The green and blue fluorescence represent AF-488-labeled KLAK peptides and the Hoechst 33342stained cell nucleus, respectively.

Cellular Association of PPNs with Cancer Cells. The efficiency of cellular association and internalization is directly related to the cytotoxicity of the PPNs, as apoptotic responses are downstream of cellular association and internalization. Therefore, cellular association was evaluated using flow cytometry and deconvolution microscopy. The AF-488-labeled KLAK peptide was used to prepare the peptide particles, and HeLa cells were incubated with these nanoparticles at a peptide concentration of $10 \mu \mathrm{M}$. Flow cytometry revealed that the cells treated with B-PPN displayed approximately 1.5-fold stronger fluorescence when compared with the cells treated with E-PPN after 9 h (Figure 3a), thus indicating more efficient association with B-PPN than with E-PPN. This result may be attributed to the higher propensity of aromatic-aliphatic mixed disulfide of 4 -DBU 33 toward disulfide exchange compared with the aliphatic disulfide of 2-DEU, thus leading to efficient anchoring to the cell surface thiols. Additionally, deconvolution microscopy showed slightly more green fluorescence from the KLAK peptides upon association with the cells in the samples treated with B-PPN when compared with that generated by the samples treated with E-PPN (Figure 3b,c). In combination with the intracellular distribution study, stronger cellular association ( 1.5-fold) was observed for BPPN. However, cellular association alone cannot completely explain the difference observed in cytotoxicity ( 4 -fold). Therefore, we investigated the disassembly behavior of the PPNs.

Triggered Disassembly of PPNs. The disassembly properties of the PPNs under reducing conditions were investigated by monitoring the SLI generated by the PPNs (Figure 4a). The SLI generated by B-PPNs and E-PPNs was stable in $10 \mu \mathrm{M} \mathrm{GSH}$, which mimics the extracellular reducing potential. Furthermore, the $D_{\mathrm{H}}$ and PDI of the two PPNs remained constant under the same condition, thereby indicating the stability of the KLAK particles (Supporting Information, Figure $\mathrm{S}_{7}$ ). In contrast, the SLI generated by both B-PPN and E-PPN decreased abruptly under simulated intracellular reducing conditions of $5 \mathrm{mM} \mathrm{GSH}$, thus suggesting disassembly of the particles. Notably, B-PPN showed a faster decrease in SLI when compared with E-PPN. The faster disassembly of B-PPN could be attributed to faster cleavage of the aromatic-aliphatic mixed disulfide of 4 -DBU when compared with the aliphatic disulfide. ${ }^{34}$ Following disassembly, the release of KLAK peptides is an important step toward inducing cytotoxic effects. Thus, the KLAK peptide release profile under reducing conditions was investigated (Figure $4 \mathrm{~b}$ ). KLAK peptides were released more quickly from B-PPN than from E-PPN, further confirming the faster cleavage of 4-DBU than 4-MEU.

Traceless Peptide Release from PPNs. Even after peptide release, the molecular pendant group on KLAK peptides alters the amphipathic nature of a KLAK peptide, possibly reducing cytotoxicity. ${ }^{41}$ Therefore, the mechanism of fragmentation of the molecular pendant groups and subsequent regeneration of pristine KLAK peptides are of significant interest. To determine the structure of the released peptide, MALDI-ToF MS analysis was conducted after disassembly of the PPNs in $5 \mathrm{mM} \mathrm{GSH}$. As a control, the free KLAK peptide was analyzed. The spectrum displayed peaks at $\mathrm{m} / \mathrm{z}$ of $\sim 1526\left([\mathrm{M}+\mathrm{H}]^{+}\right)$and $\sim 1548\left([\mathrm{M}+\mathrm{Na}]^{+}\right)$ (Figure $5 \mathrm{a}$ ). After $2 \mathrm{~h}$ of incubation, peaks relating to unmodified KLAK peptides were clearly detected from the peptides from B-PPNs (Figure $5 \mathrm{~b}$ ). Furthermore, there was no substantial evidence of the existence of KLAK peptides containing the 4-mercaptobenzyl urethane (4-MBU, molecular weight: $167.2 \mathrm{~g} \mathrm{~mol}^{-1}$ ) moiety. This result indicates the reversible release of unmodified KLAK peptides under reducing conditions from B-PPN. In contrast, the spectrum of E-PPN displayed weak peak signals from the unmodified KLAK peptides after $2 \mathrm{~h}$ of incubation in $5 \mathrm{mM} \mathrm{GSH}$. Additional peaks relating to the modified KLAK peptides that contained 2-mercaptoethyl urethane (2-MEU, molecular weight: 104.1 $\mathrm{g} \mathrm{mol}^{-1}$ ) moieties, as major species, were 
a)

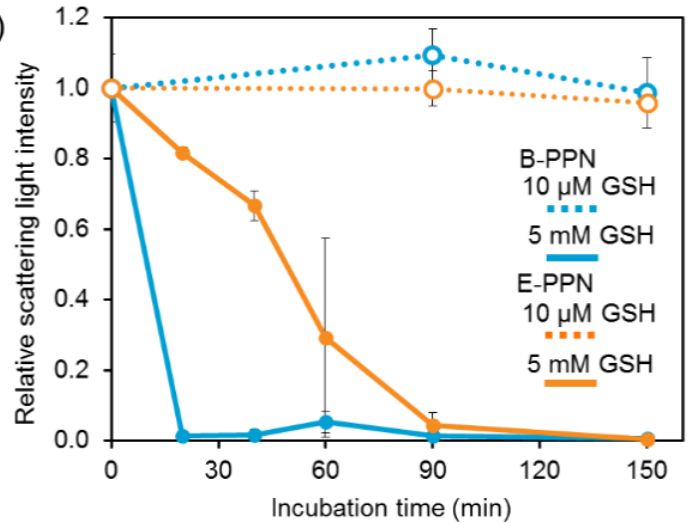

b)

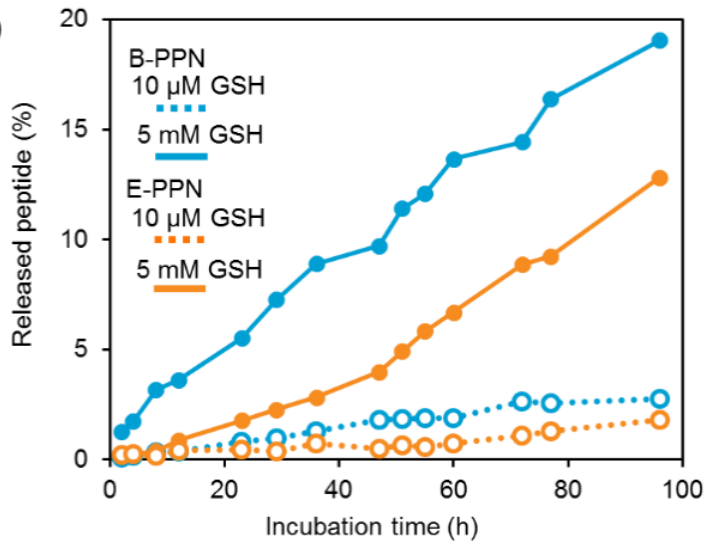

Figure 4. (a) Variations in the scattering light intensity generated from B-PPNs and E-PPNs in $5 \mathrm{mM}$ and $10 \mu \mathrm{M} \mathrm{GSH}$. Error bars represent standard deviations of means obtained from three samples. (b) Release of KLAK peptides from BPPNs and E-PPNs in $5 \mathrm{mM}$ and $10 \mu \mathrm{M} \mathrm{GSH}$.
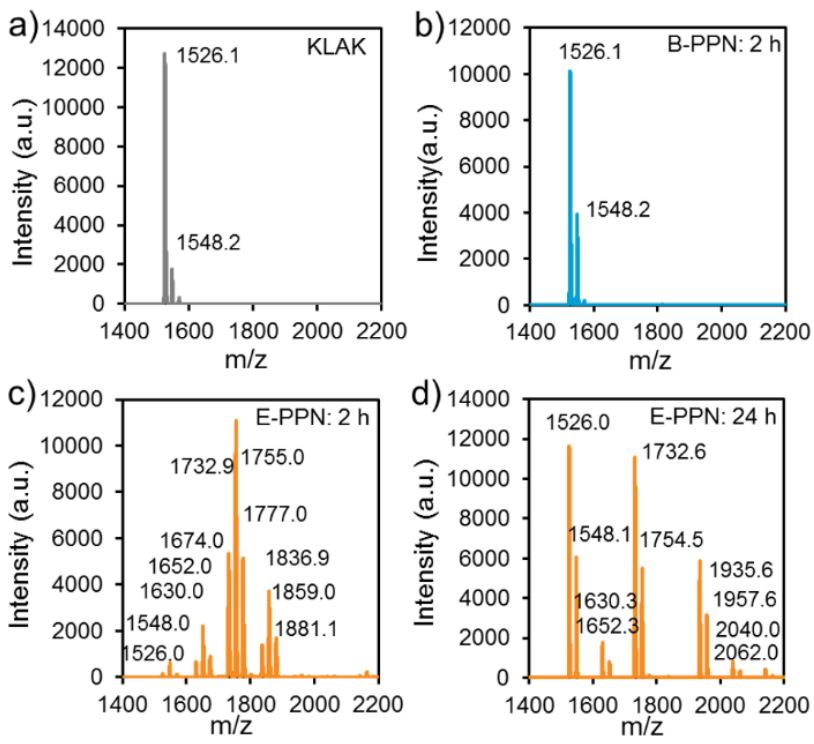

Figure 5. Molecular weight analysis of the peptides released from the PPNs. MALDI-ToF MS spectra of (a) free KLAK peptides and KLAK peptides released from (b) B-PPNs after 2 $\mathrm{h}$ of incubation in $5 \mathrm{mM} \mathrm{GSH}$, and E-PPNs after (c) $2 \mathrm{~h}$ and (d) $24 \mathrm{~h}$ of incubation in $5 \mathrm{mM} \mathrm{GSH}$. observed (Figure 5c). After prolonged incubation for $24 \mathrm{~h}$, the peptides, which were released from B-PPNs, showed major peaks, corresponding to free KLAK peptides (Supporting Information, Figure S18). In contrast, peaks relating to the 2-MEU moieties-containing KLAK peptides, which were released from E-PPNs, were clearly observed (Figure $5 d$ ). A significant amount of free KLAK peptide was also detected. These results suggest that both 4-DBU and 2DEU moieties can be cleaved under physiologically relevant reducing conditions (i.e., $5 \mathrm{mM} \mathrm{GSH}$ ). However, the removal of the molecular pendant groups is significantly quicker for the 4-MBU moiety when compared with that of the 2-MEU moiety. The faster release of unmodified KLAK peptides under intracellular reducing conditions would lead to more efficient induction of apoptosis, possibly resulting in higher cytotoxicity to cells.

Application of PPNs for Therapeutic Delivery. To investigate the application of PPNs for therapeutic delivery, DOX, as a representative small molecule drug, was incorporated into the PPNs by covalent conjugation to PPNs using the above established reversible disulfide linkages. DOX was first modified with either NDBC or NDEC and then immobilized onto MSNs together with KLAK peptides. After cross-linking and template removal, DOX-loaded PPNs were obtained, as confirmed by the red coloration of the pellets and DLS and TEM analyses (Supporting Information, Figure S19, Figure 6a, and Table 2). Both the DOX-free and DOXloaded PPNs had comparable $D_{\mathrm{H}}$, PDI, and $\zeta$-potential values. Even after DOX loading, the PPNs maintained colloidal stability under physiological salt conditions (Supporting Information, Figure S2o). The amount of DOX loading could be readily tuned by adjusting the feed ratio of DOX and KLAK peptides during immobilization (Table 2). The particles prepared at KLAK/DOX molar ratios of 1.0:1.3 and 1.0:0.3 are denoted as $\mathrm{DOX}_{1.3} @ \mathrm{~B}-\mathrm{PPNs}$ (or DOX $\mathrm{DOX}_{1.3} @ \mathrm{E}-\mathrm{PPNs}$ ) and $\mathrm{DOX}_{\mathrm{o.3}} @ \mathrm{~B}-\mathrm{PPN}$, respectively. The DOX-loaded peptide nanoparticles disassembled selectively in simulated intracellular conditions (5 $\mathrm{mM}$ GSH) (Supporting Information, Figure S21). DOX was also readily released in such a simulated intracellular reducing environment $(5 \mathrm{mM}$ $\mathrm{GSH})$. In contrast, release was significantly limited in $10 \mu \mathrm{M}$ GSH, which simulates the extracellular reducing environment (Figure 6b). A faster release of DOX was

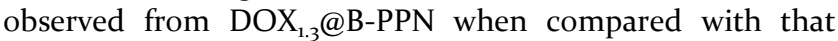
from $\mathrm{DOX}_{1.3} @ \mathrm{E}-\mathrm{PPN}$. This result was consistent with the disassembly study conducted on B-PPN and E-PPN. Notably, an initial burst release was not observed, as is often reported for other systems and results in the cytotoxicity to normal cells. ${ }^{5^{1}}$ Thus, selective drug release in intracellular reducing conditions can be realized using the present system, thereby reducing risks of undesirable side effects to normal cells from an initial surge in drug concentration upon drug administration. In this regard, the selective cytotoxicity to the cancer cells may be further improved by facile incorporation of amine-containing targeting ligands, which will be investigated in our future work. The cytotoxicity of the DOX-loaded PPNs was examined by XTT assays (Figure 6c). DOX $_{1.3} @ B-P P N$ prepared from NDBC chemistry exerted higher cytotoxicity against HeLa cells when compared with DOX $_{1.3} @ E-P P N$ prepared from NDEC chemistry. Deconvolution microscopy analysis revealed the intracellular distribution of DOX. In the cells treated with DOX $\mathrm{D}_{1.3} @ \mathrm{~B}-\mathrm{PPN}$, 


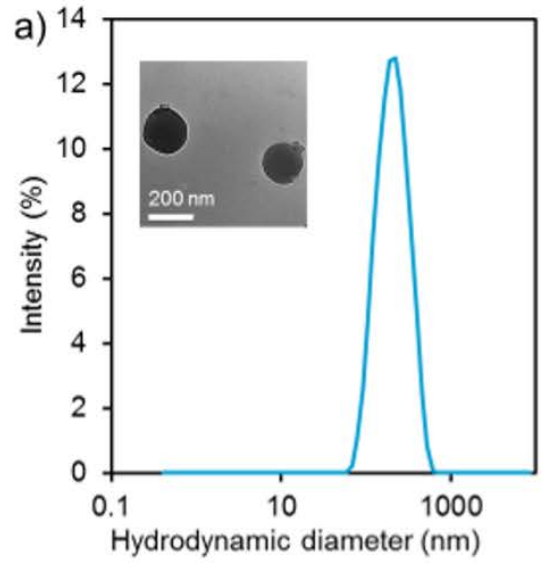

d) DOX $1.3 @ B-P P N$

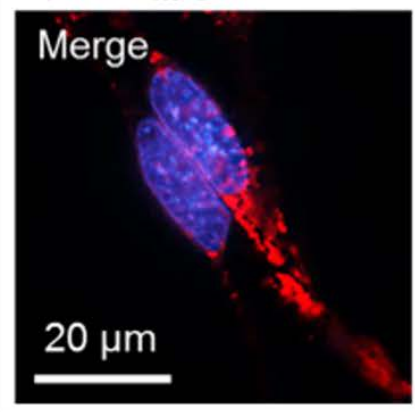

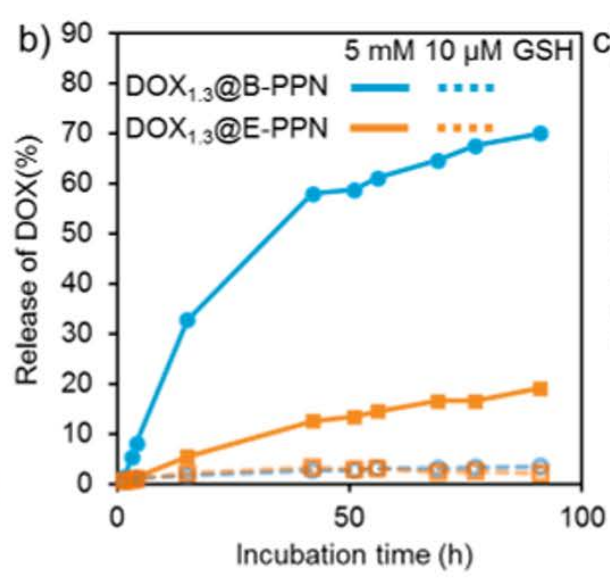

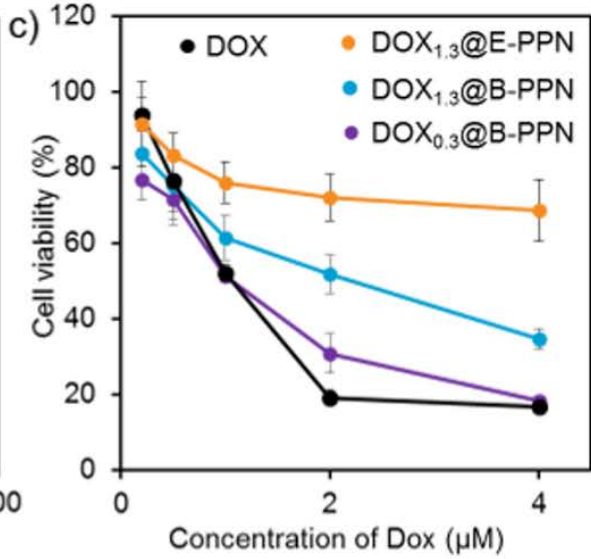

e) DOX $1.3 @ E-P P N$

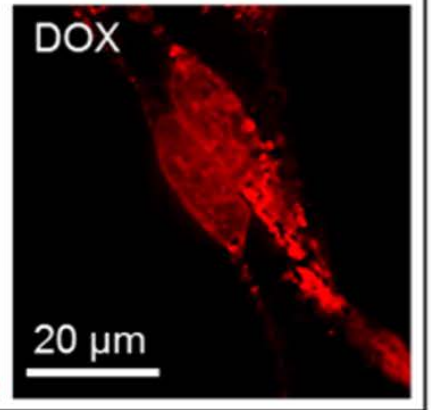

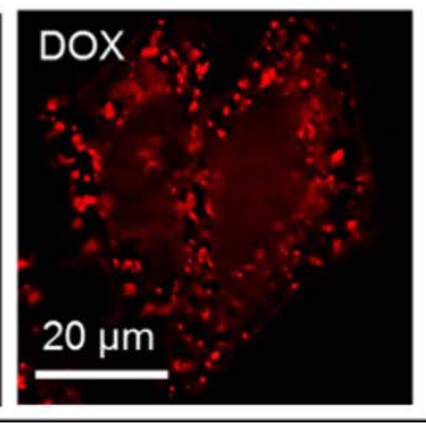

Figure 6. Physicochemical characterization and bioactivity evaluation of DOX-loaded PPNs. (a) Size distribution and TEM image (inset) of DOX $\mathrm{DOX}_{1.3} @ \mathrm{~B}-\mathrm{PPN}$. (b) DOX release profiles from DOX $\mathrm{DOX}_{1.3} @ \mathrm{~B}-\mathrm{PPN}$ and DOX $\mathrm{DO}_{1.3} @ \mathrm{E}-\mathrm{PPN}$ in 5 mM and $10 \mu \mathrm{M}$ GSH. (c) Cytotoxicity of free DOX and DOX-loaded PPNs prepared using different disulfide linkages $\left(\mathrm{DOX}_{1.3} @ \mathrm{~B}-\mathrm{PPN}, \mathrm{DOX}_{\mathrm{0.3}} @ \mathrm{~B}-\mathrm{PPN}\right.$, DOX $\left._{1.3} @ E-P P N\right)$ and different DOX loadings. Error bars represent standard deviations of the means obtained from six samples.

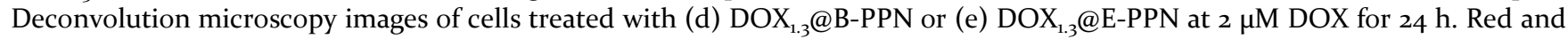
blue fluorescence represent DOX and Hoechst 33342, respectively.

Table 2. Physicochemical Properties of PPNs Loaded with DOX

\begin{tabular}{ccccccc}
\hline & Chemistry & $\begin{array}{l}\text { Hydrodynamic } \\
\text { Diameter, } D_{\mathrm{H}} \\
(\mathrm{nm})^{\mathrm{a}}\end{array}$ & PDI $^{\mathrm{a}}$ & $\begin{array}{c}\zeta \text { - } \\
\text { potential } \\
(\mathrm{mV})^{\mathrm{a}}\end{array}$ & $\begin{array}{l}\text { Feed } \\
\text { KLAK/DOX } \\
\text { molar ratio }\end{array}$ & $\begin{array}{l}\text { Loaded } \\
\text { KLAK/DOX } \\
\text { molar ratio }\end{array}$ \\
\hline DOX $_{0.3} @ \mathrm{~B}-\mathrm{PPN}$ & NDBC & $188 \pm 22$ & $0.16 \pm 0.10$ & $2 \pm 1$ & $1.0: 0.3$ & $1.0: 0.8$ \\
DOX $_{1.3} @ \mathrm{~B}-\mathrm{PPN}$ & $\mathrm{NDBC}$ & $187 \pm 8$ & $0.14 \pm 0.10$ & $2 \pm 1$ & $1.0: 1.3$ & $1.0: 2.3$ \\
DOX $_{1.3} @ \mathrm{E}-\mathrm{PPN}$ & $\mathrm{NDEC}$ & $188 \pm 12$ & $0.17 \pm 0.10$ & $2 \pm 1$ & $1.0: 1.3$ & $1.0: 2.4$
\end{tabular}

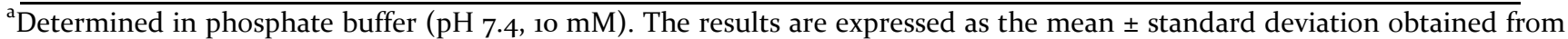
four samples.

strong DOX fluorescence was observed in the nucleus, indicating significant accumulation of DOX in the nucleus (Figure 6d). In contrast, such localization was less pronounced in cells treated with DOX $\mathrm{DO}_{13} @ \mathrm{E}-\mathrm{PPN}$ (Figure 6e). The lower nuclear distribution of DOX released from DOX $_{1.3} @ E-P P N$ could be attributed to slower cleavage of disulfide and subsequent fragmentation of the 2-MEU moiety over the 4-MBU moiety, thus resulting in slower accumulation of DOX in the nucleus. These results indicate that the selection of reversible disulfide chemistry significantly alters the intracellular distribution and activity of therapeutics loaded within PPNs. Such a phenomenon may prove useful in the design of nanocarrier systems with tunable intracellular therapeutics activity. 4-DBU is suitable when abrupt increases in drug concentration (release) is required, whereas 2-MEU is more appropriate when gradual sustained drug release is desired.

PPNs allow co-delivery of KLAK peptides and DOX, possibly imparting a tunable cytotoxicity to the DOX-loaded peptide nanoparticles. To examine the effect of co-delivery of

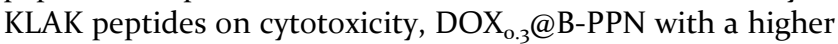

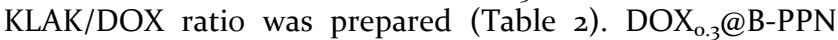
exhibited stronger cytotoxicity when compared with $\mathrm{DOX}_{1.3} @ \mathrm{~B}-\mathrm{PPN}$ at a given DOX concentration. This result was attributed to the higher content of KLAK peptide (3fold) in $\mathrm{DOX}_{0.3} @ \mathrm{~B}-\mathrm{PPN}$ when compared with that in 
DOX $_{1.3} @ B-P P N$, thus leading to a greater delivery of KLAK peptides together with DOX. Notably, the degree of the enhanced cytotoxicity was much greater than expected from the cytotoxicity study of DOX-free B-PPN (Figure 2a). For example, approximately $25 \%$ difference in the cell viability was observed between DOX $\mathrm{D}_{0.3} @ \mathrm{~B}-\mathrm{PPN}$ and DOX $\mathrm{D}_{1.3} @ \mathrm{~B}-\mathrm{PPN}$ at $2 \mu \mathrm{M}$ DOX, which corresponds to the KLAK peptide concentration of $0.9 \mu \mathrm{M}$ for $\mathrm{DOX}_{1.3} @ \mathrm{~B}-\mathrm{PPN}$, and $2.5 \mu \mathrm{M}$ for DOX $_{0.3} @ B-P P N$. Meanwhile, DOX-free B-PPN displayed negligible cytotoxicity at $2.5 \mu \mathrm{M}$ of KLAK peptides (Figure 2a). These results suggest synergistic cell killing when KLAK peptide and DOX are combined.

\section{CONCLUSION}

The functional peptide particles, or PPNs, from KLAK peptides were engineered via template-assisted assembly using reversible cross-linking chemistries based on disulfides The resulting peptide nanoparticles exerted tunable cytotoxicity against cancer cells, depending on the reversible chemistries. A marked difference was observed in the cytotoxicity of the PPNs prepared using reversible 4-DBU and 2-DEU chemistries, with the PPNs prepared using 4DBU chemistry exhibiting stronger cytotoxicity than those prepared using 2-DEU chemistry. The stronger cytotoxicity displayed by the former PPNs could be attributed to faster disulfide cleavage and subsequent fragmentation of molecular pendant groups on the KLAK peptides. These resulted in regeneration of pristine peptides, inducing cell death. The facile conjugation and loading of a small molecular drug into the peptide particles was also demonstrated using DOX with a single conjugation site. The release of DOX and hence the cytotoxicity of the DOXloaded peptide particles were also tunable by the conjugation chemistry. Furthermore the use of KLAK peptides as constituent materials afforded co-delivery of KLAK peptides and DOX, thereby providing the DOX-loaded peptide nanoparticles with tunable cytotoxicity, highlighting the potential of PPNs in therapeutic delivery applications.

\section{ASSOCIATED CONTENT}

\section{Supporting Information}

Scheme for synthesis of chemicals (Scheme $\mathrm{S}_{1}$ ), chemical characterization data $\left({ }^{1} \mathrm{H}\right.$ NMR and ${ }^{13} \mathrm{C}$ NMR spectra; Figures $\mathrm{S}_{1}-\mathrm{S}_{14}$ ), change in hydrodynamic diameter and polydispersity index of PPNs in phosphate-buffered saline (Figure S15) and in $10 \mu \mathrm{M}$ GSH (Figure S17), fluorescence microscopy images of HeLa cells stained by annexin $\mathrm{V}-\mathrm{AF}_{4} 88$ and PI positive cells following treatment with PPNs and free peptide (Figure S16), MALDI-ToF MS spectrum of KLAK peptides released from B-PPNs after $2 \mathrm{~h}$ of incubation in $5 \mathrm{mM}$ GSH (Figure S18), a photograph of the pellet of DOX $_{1.3} @ B-P P N$ (Figure S19), change in hydrodynamic diameter and polydispersity index of $\mathrm{DOX}_{1.3} @ \mathrm{~B}-\mathrm{PPNs}$ in phosphate-buffered saline (Figure S20), change in scattering light intensity of DOX1.3@B-PPNs in $5 \mathrm{mM}$ and $10 \mu \mathrm{M}$ GSH (Figure S21), and $\mathrm{IC}_{50}$ and $\mathrm{EC}_{50}$ values of PPNs (Table $\mathrm{S}_{1}$ ). This material is available free of charge via the Internet at http://pubs.acs.org.

\section{AUTHOR INFORMATION}

\section{Corresponding Author}

*E-mail: fcaruso@unimelb.edu.au.

\section{Notes}

The authors declare no competing financial interest.

\section{ACKNOWLEDGMENT}

This research was conducted and funded by the Australian Research Council (ARC) Centre of Excellence in Convergent Bio-Nano Science and Technology (Project CE140100036) and the ARC under the Australian Laureate Fellowship (F.C., FL120100030) scheme. This work was performed in part at the Materials Characterisation and Fabrication Platform (MCFP) at the University of Melbourne and the Victorian Node of the Australian National Fabrication Facility (ANFF).

\section{REFERENCES}

(1) Fosgerau, K.; Hoffmann, T. Drug Discov. Today 2015, 20, 122.

(2) Kaspar, A. A.; Reichert, J. M. Drug Discov. Today 2013 , 18,807 .

(3) Cotter, P. D.; Ross, R. P.; Hill, C. Nat. Rev. Microbiol. 2013, 11, 95 .

(4) Avan, I.; Hall, C. D.; Katritzky, A. R. Chem. Soc. Rev. 2014, 43, 3575 .

(5) Vlieghe, P.; Lisowski, V.; Martinez, J.; Khrestchatisky, M. Drug Discov. Today 2010, 15, 40.

(6) Fjell, C. D.; Hiss, A. J.; Hancock, R. E. W.; Schneider, G. Nat. Rev. Drug Discov. 2012, 11, 37.

(7) Tibbit, M. W.; Dahlman, J. E.; Langer, R. J. Am. Chem. Soc. 2016, 138, 704 .

(8) Mitragotri, S.; Anderson, D.; Chen, S.; Chow, E.; Ho, D.; Kavanov, A.; Karp, J.; Kataoka, K.; Mirkin, C.; Petrosko, S.; Shi, J.; Stevens, M. M.; Sun, S.; Teoh, S.; Venkatraman, S. S.; Xia, Y.; Wang, S.; Gu, Z.; Xu, C. ACS Nano 2015, 9, 6644.

(9) Matougui, N,; Boge, L.; Groo, A.-C.; Umerska, A.; Ringstad, L.; Bysell, H.; Saulnier, P. Int. J. Pharm. 2016, 502, 80.

(10) Malmsten, M. Curr. Opin. Colloid Interface Sci. 2013, 18, 468.

(11) Evans, B. C.; Hocking, K. M.; Kilchrist, K. V.; Wise, E. S.; Brophy, C. M., Duvall, C. L. ACS Nano 2015, 9, 5893.

(12) Patel, A.; Patel, M.; Yang, X. Mitra, A. K. Protein Pept. Lett. 2014, 21, 1102-1120.

(13) van Elk, M.; Murphy, B. P.; Eufrásio-de-Silva, T.; O'Reilly, D. P.; Vermonden T.; Hennink, W. E.; Duffy, G. P.; Ruiz-Hernández, E. Int. J. Pharm. 2016, 515, 132.

(14) Baba, K.; Pudavar, H. E.; Roy, I.; Ohulchanskyy, T. Y.; Chen, Y.; Pandey, R. K.; Prasad, P. N. Mol. Pharm. 2007, 4, 289.

(15) Kasai, H.; Murakami, T.; Ikuta, Y.; Koseki, Y.; Baba, K.; Oikawa, H.; Nakanishi, H.; Okada, M.; Shoji, M.; Ueda, M.; Imahori, H.; Hashida, M. Angew. Chem. Int. Ed. 2012, 51, 10315.

(16) Eskandari, S.; Guerin, T.; Toth, I.; Stephenson, R. J. Adv. Drug Deliv. Rev. 2016, DOI: 10.1016/j.addr.2016.06.013.

(17) Sigg, S. J.; Postupalenko, V.; Duskey, J. T.; Palivan, C. G.; Meier, W. Biomacromolecules 2016, 17, 935.

(18) Korevaar P. A.; Newcomb, C. J.; Meijer, E. W.; Stupp, S. I. J. Am. Chem. Soc. 2014, 136, 8540.

(19) Qiao, Z.-Y.; Hou, C.-Y.; Zhang, D.; Liu, Y.; Lin, Y.-X.; An, H.-W.; Li, X.-J.; Wang, H. J. Mater. Chem. B 2015, 3, 2943.

(20) Ikeda, Y.; Nagasaki, Y. Adv. Polym. Sci. 2012, 247, 115

(21) Shechter, Y.; Mironchik, M.; Saul, A.; Gershonov, E.; Precido-Patt, L.; Sasson, K.; Tsubery, H.; Mester, B.; Kapitkovsky, A.; Rubinraut, S.; Vachutinski, Y.; Fridkin, G.; Fridkin, M. Int. J. Pept. Res. Ther. 2007, 13, 105.

(22) Zalipsky, S.; Mullah, N.; Engbers, C.; Hutchins, M. U.; Kiwan, R. Bioconjugate Chem. 20o7, 18, 1869. 
(23) Chen, J.; Zhao, M.; Feng, F.; Sizovs, A.; Wang, J. J. Am. Chem. Soc. 2013, 135, 10938.

(24) Wang, Y.; Yu, A.; Caruso, F. Angew. Chem. Int. Ed. 2005, 44, 2888.

(25) Wang, Y.; Caruso, F. Adv. Mater. 2oo6, 18, 795.

(26) Cui, J.; van Koeverden, M. P.; Müllner, M.; Kempe, K.; Caruso, F. Adv. Colloid Interface Sci. 2014, 207, 14.

(27) Schafer, F. Q.; Buettner, G. R. Free Radical Biol. Med. 2001, 30, 1191.

(28) Saito, G.; Swanson, J. A.; Lee, K.-D. Adv. Drug Deliv. Rev. 2003, 55, 199.

(29) Olm, E.; Fernandes, A. P.; Hebert, C.; Rundlöf, A.-K. Larsen, E. H.; Danielsson, O.; Björnstedt, M. Proc. Natl. Acad. Sci. U.S.A. 2009, 106, 11400.

(30) Carlsson, J.; Drevin, H.; Axén, R. Biochem. J. 1978, 173, 723.

(31) Xu, J.; Wang, J.; Luft, J. C.; Tian, S.; Owens, G.; Pandya, A. A.; Berglund, P.; Pohlhaus, P.; Maynor, B. W.; Smith, J.; Hubby, B.; Napier, M. E.; DeSimone, J. M. J. Am. Chem. Soc. 2012, 134, 8774 .

(32) Gong, Y.; Leroux, J.-C.; Gauthier, M. A. Bioconjugate Chem. 2015, 26, 1172.

(33) Senter, P. D.; Pearce, W. E.; Greenfield, R. S. J. Org. Chem. 1990, 55, 2975.

(34) Zalipsky, S.; Qazen, M.; Walker, J. A.; Mullah, N.; Quinn, Y. P.; Huang, S. K. Bioconjugate Chem. 1999, 10, 703.

(35) Pires, M. M.; Chmielewski, J. Org. Lett. 2008, 10, 837.

(36) Sun, T.; Morger, A.; Castagner, B.; Leroux, J.-C. Chem. Commun. 2015, 51, 5721.

(37) Suma, T.; Cui, J.; Müllner, M.; Ju, Y.; Guo, J.; Hu, M.; Caruso, F. ACS Macro Lett. 2015, 4, 160.

(38) Rozema, D. B.; Ekena, K.; Lewis, D. L.; Loomis, A. G.; Wolff, J. A. Bioconjugate Chem. 2003, 14, 51.
(39) Lee, Y.; Miyata, K.; Oba, M.; Ishii, T.; Fukushima, S.; Han, M.; Koyama, H.; Nishiyama, N.; Kataoka, K. Angew. Chem. Int. Ed. 2008, 47, 5163.

(40) Yoshii, T.; Onogi, S.; Shigemitsu, H.; Hamachi, I. J. Am. Chem. Soc. 2015, 137, 3360.

(41) Javadpour, M. M.; Juban, M. M.; Lo, W.-C. J.; Bishop, S. M.; Alberty, J. B.; Cowell, S. M.; Becker, C. L.; McLaughlin, M. L. J. Med. Chem. 1996, 39, 3107.

(42) Ellerby, H. M.; Arap, W.; Ellerby, L. M.; Kain, R.; Andrusiak, R.; Rio, G. D.; Krajewski, S.; Lombardo, C. R.; Rao, R.; Ruoslahti, E.; Bredesen, D. E.; Pasqualini, R. Nat. Med. 1999, 5, 1032.

(43) Ko, Y. T.; Falcao, C.; Torchilin, V. P. Mol. Pharm. 2oo9, 6, 971.

(44) Agemy, L.; Friedmann-Morvinski, D.; Kotamraju, V. R.; Roth, L.; Sugahara, K. N.; Girard, O. M.; Mattrey, R. F.; Verma, I. M.; Ruoslahti, E. Proc. Natl. Acad. Sci. U.S.A. 2011, 108, 17450.

(45) Moktan, S.; Raucher, D. Int. J. Pept. Res. Ther. 2012, 18, 227.

(46) Lee, B. R.; Oh, K. T.; Oh, Y. T.; Baik, H. J.; Park, S. Y.; Youn, Y. S.; Lee, E. S. Chem. Commun. 2011, 47, 3852.

(47) Zhang, K.; Xu, L. L.; Jiang, J. G.; Calin, N.; Lam, K. F.; Zhang, S. J.; Wu, H. H.; Wu, G. D.; Albela, B.; Bonneviot, L.; Wu, P. J. Am. Chem. Soc. 2013, 135, 2427.

(48) Lowry, O. H.; Rosebrough, N. J.; Farr, A. L.; Randall, R. J. J. Biolog. Chem. 1951, 193, 265.

(49) Vallejo, C. G.; Lagunas, R. Anal. Biochem. 197o, 36, 207.

(50) Hyun, S.; Lee, S.; Kim, S.; Jang, S.; Yu, J.; Lee, Y. Biomacromolecules 2014, 15, 3746.

(51) Huang, X.; Brazel, C. S. J. Controlled Release 2001, 73, 121. 
Table of Contents entry

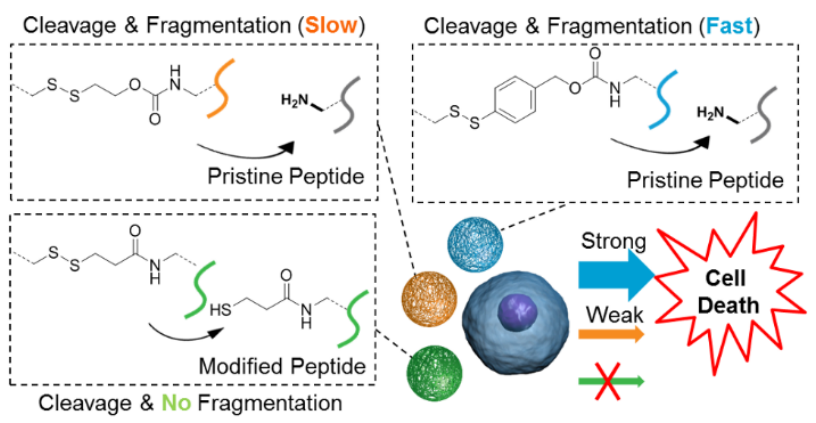

